\title{
TUTORIAL TEKNOLOGI HIDROPONIK DENAGAN MENGGUNAKAN MEDIA WICK ROLL SEBAGAI ALTERNATIF KETAHANAN PANGAN PANDEMI COVID-19 MASYARAKAT KELURAHAN SINDANGSARI KABUPATEN TANGERANG
}

\author{
Rikza Fauzan, Lanina Benita Indah Putri \\ Universitas Sultan Ageng Tirtayasa \\ rikza.fauzan@untirta.ac.id
}

\begin{abstract}
Abstrak
Tujuan dari kegiatan tutorial teknologi hidroponik dengan memanfaatkan media wick roll adalah tantangan bagi masyarakat dalam ketahanan pangan selama masa pandemic covid-19 sekaligus juga memberdayakan rumah tangga dan masyarakat Kelurahan Sindangsari Kabupaten Tangerang dalam penyediaan sumber pangan dan gizi melalui optimalisasi pemanfaatan pekarangan dan lahan sekitar tempat tinggal meningkatkan kesadaran, peran, dan partisipasi masyarakat dalam mewujudkan pola konsumsi pangan yang beragam, bergizi seimbang dan aman. Upaya yang dilakukan adalah dengan mengembangkan program GERMAS (Gerakan Masyarakat Sehat) di lingkungan rumah. Salah satu kegiatan dari kegiatan yang dilakukan dalam rangka mengembangkan KRPL adalah kegiatan pelatihan pengembangan budidaya sayuran dengan sistem hidroponik. Pelatihan dan pengembangan dudidaya tanaman dengan sistem hidroponik yang telah dilaksanakan mahasiswa KKM 140 Universitas Sultan Agung Trtayasa. Setelah dilakukan pelatihan, peserta pelatihan memahami dan mempunyai keterampilan dalam membudidayakan sayuran dengan sistem hidroponik dengan berbagai metode yaitu wick system, NFT Sistem (Nutrient Film Technique) dan DFT Sistem (Deep Flow Technique)setelah dilakukan pelatihan memahami penanganan sayuran setelah panen dan memahami memahami bagaimana strategi yang harus dilakuakan dalam memasaran sayuran sistem hidroponik. Kegiatan tutorial dilakukan secara daring dengan memanfaatkan aplikasi youtube.
\end{abstract}

\section{Kata kunci: Hidroponik, Nutrient Film Technique, Deep Flow Technique}

\section{A. PENDAhUluan}

Pandemi Covid-19 yang mulai berkembang akhir tahun 2019 menyebabkan kelumpuhan holistik setiap Negara di Dunia termasuk Indonesia. Sektor-sektor produktif Negara Indonesia terkena imbas akibat penyebaran Covid-19 yang sangat sangat massif sehingga banyaknya korban meninggal akibat virus. Berbagai upaya memperbaiki kondisi khususnya ekonomi adalah penerapan new normal untuk menstimulus kegiatan produktif masyarakat agar tetap bertahan dalam kondisi ekonomi yang sedang turun. Tidak hanya dalam bidang pendidikan, ekonomi, dan kesehatan, ketahanan pangan 


\section{Ourrale}

masyarakat merupakan sektor yang sangat vital diperlukan alternatif dan solusi secara konkrit masa pandemi ini.

Salah satu tantangan bagi Negara Indonesia pada tahun 2020 saat ini adalah Upaya dalam pemenuhan kebutuhan pangan merupakan suatu keharusan karena pangan merupakan salah satu kebutuhan dasar manusia. Menurut Undang-undang Nomor 18 Tahun 2012 tentang pangan, bahwa pangan adalah segala sesuatu yang berasal dari sumber hayati produk pertanian, perkebunan, kehutanan, perikanan, peternakan, perairan, dan air,baik yang diolah maupun tidak diolah yang diperuntukkan sebagai makanan atau minuman bagi konsumsi manusia, termasuk bahan tambahan pangan, bahan baku pangan, dan bahan lainnya yang digunakan dalam proses penyiapan, pengolahan, dan/atau pembuatan makanan atau minuman.

Selanjutnya pada Undang-undang tentang pangan tersebut tersebut dinyatakan bahwa bahwa pangan merupakan kebutuhan dasar manusia yang paling utama dan pemenuhannya merupakan bagian dari hak asasi manusia yang dijamin di dalam Undang-Undang Dasar Negara Republik Indonesia Tahun 1945 sebagai komponen dasar untuk mewujudkan sumber daya manusia yang berkualitas. Berdasarkan Undang-undang tersebut bahwa negara berkewajiban mewujudkan ketersediaan, keterjangkauan, dan pemenuhan konsumsi Pangan yang cukup, aman, bermutu, dan bergizi seimbang, baik pada tingkat nasional maupun daerah hingga perseorangan secara merata di seluruh wilayah Negara Kesatuan Republik Indonesia sepanjang waktu dengan memanfaatkan sumber daya, kelembagaan, dan budaya lokal.

Selanjutnya Instruksi presiden republik indonesia nomor 1 tahun 2017 mengenai Gerakan Masyarakat Sehat (GERMAS) adalah sebuah gerakan yang bertujuan untuk memasyarakatkan budaya hidup sehat serta meninggalkan kebiasaan dan perilaku masyarakat yang kurang sehat. Aksi ini juga diikuti dengan memasyarakatkan perilaku hidup bersih sehat dan dukungan untuk program infrastruktur dengan basis masyarakat. Program ini memiliki beberapa fokus seperti membangun akses untuk memenuhi kebutuhan air minum, instalasi kesehatan masyarakat serta pembangunan pemukiman yang layak huni. Ketiganya merupakan infrastruktur dasar yang menjadi pondasi dari gerakan masyarakat 


\section{Sivrnal}

hidup sehat salah satunya adalah megkonsumsi sayuran dan buah.

Hal tersebut sejalan dengan Undang-undang Nomor 18 tahun 2012 menjelaskan bahwa Pemenuhan pangan tidak hanya sekedar memenuhi kuantitas pangan tetapi juga kualitasnya. Penjabaran dari Undang-Undang Pangan tersebut telah diterbitkan Peraturan Pemerintah Nomor 17 Tahun 2015 tentang Ketahanan Pangan dan Gizi dimana dalam Pasal 26 disebutkan bahwa upaya penganekaragaman pangan salah satunya dilakukan melalui pemanfaatan lahan pekarangan. Badan Ketahanan Pangan melalui Pusat Penganekaragaman Konsumsi dan Keamanan Pangan pada tahun 2018 meluncurkan Konsep Kawasan Rumah Pangan Lestari (KRPL), dalam rangka mempercepat penganekaragaman pangan dan memperkuat ketahanan pangan masyarakat, dengan adanya anjuran pemanfaatan pekarangan sangatlah tepat untuk memenuhi pangan dan gizi keluarga, mengingat selama ini pekarangan dan lahan disekitar lainnya belum dimanfaatkan secara optimal. Padahal lahan tersebut memiliki potensi untuk dikembangkan sebagai penghasil pangan, dalam memperbaiki gizi keluarga sekaligus meningkatkan pendapatan keluarga.
Manfaatnya sangat besar, terutama bagi masyarakat golongan ekonomi lemah. Untuk itu Pemerintah telah menganjurkan agar memanfaatkan setiap jengkal tanah termasuk lahan tidur, galengan, maupun tanah kosong yang tidak produktif (Kementerian Pertanian Republik Indonesia Indonesia, 2018).

Melalui kegiatan ini diharapkan dapat meningkatkan kualitas konsumsi pangan masyarakat untuk membentuk pola konsumsi pangan yang baik. program GERMAS (Gerakan Masyarakat Sehat) juga dilaksanakan dalam rangka mendukung program pemerintah untuk penurunan kemiskinan melalui kegiatan padat karya, penanganan daerah stunting, serta penanganan daerah rentan rawan pangan. Untuk mempercepat akselerasi gerakan pemanfaatan pekarangan melalui program GERMAS (Gerakan Masyarakat Sehat), perlu dijalin kerja sama kemitraan dengan pihak swasta, antara lain berupa Corporate Social Responsibility (CSR)/Program Kemitraan dan Bina Lingkungan (PKBL). Kerjasama tersebut dapat dilakukan baik bidang pangan maupun bidang lainnya seperti pendidikan dengan sosialisasi kepada anak usia dini atau masyarakat lainnya (Kementerian 


\section{Ourrallemes}

Pertanian Republik Indonesia Indonesia, 2018).

Pelaksanaan program GERMAS

(Gerakan Masyarakat Sehat) perlu dilakukan secara terintegrasi dengan kegiatan lainnya, baik dalam pelaksanaan maupun pembiayaannya. Tujuan dari program GERMAS (Gerakan Masyarakat Sehat) adalah memberikan penyuluhan kesehatan dan memberdayakan rumah tangga dan masyarakat dalam penyediaan sumber pangan dan gizi melalui optimalisasi pemanfaatan pekarangan dan lahan sekitar tempat tinggal; meningkatkan kesadaran, peran, dan partisipasi masyarakat dalam mewujudkan pola konsumsi pangan yang beragam, bergizi seimbang dan aman (Kementerian Pertanian Republik Indonesia Indonesia, 2018).

Hal tersebut sejalan dengan program kelurahan Sindangsari yang berupaya menganjurkan gaya hidup sehat dengan pola gizi seimbang sesuai dengan Program "GERMAS" (Gerakan Masyarakat Sehat) sebagai upaya pencegahan terhadap gangguan kesehatan keluarga. Upaya yang dilakukan adalah dengan mengembangkan program GERMAS (Gerakan Masyarakat Sehat) di lingkungan rumah. Salah satu kegiatan dari kegiatan yang dilakukan dalam rangka mengembangkan program GERMAS (Gerakan Masyarakat Sehat) adalah membuat video tutorial kegiatan pengembangan budidaya sayuran dengan sistem hidroponik. Budidaya tanaman dengan sistem hidroponik adalah metode bercocok tanam dengan memanfaatkan air yang dipercaya dengan unsur hara (nutrisi) untuk pertumbuhan dan perkembangan tanaman. Sistem tanam hidroponik ini sangat cocok di aplikasikan di lahan kecil dan sifatnya lebih ramah lingkungan, sehingga menarik minat masyarakat untuk bercocock tanam (Rahmat, 2016). Terdapat beberapa keistimewaan sayuran yang dibudidayakan dengan sistem hidroponik, yaitu simple (mudah) dan harganya lebih mahal dari harga sayuran biasa selain itu budidaya tanaman dengan sistem hidroponik tidak memerlukan lahan yang luas sehingga dapat diterapkan di lingkungan perumahan. Pengembangan budidaya sayuran dengan sistem hidroponik di Kelurahan Sindangsari, selain untuk memenuhi kebutuhan gizi keluarga, juga dapat meningkatkan pendapatan. Berdasarkan hal tersebut maka dilakukan kerjasama antara KKM 140 Universitas Sultan Ageng Tirtayasa dengan Kelurahan Sindangsari Kabupaten 
Tangerang dengan melaksanakan kegiatan pelatihan dan pendampingan. Tujuan dari kegiatan tersebut adalah untuk memberikan pengetahuan dan keterampilan bagi masyarakat tentang budi daya tanaman dengan sistem hidroponik.

\section{B. METODE DAN BAHAN}

Tutorial ini memanfaatkan aplikasi youtube dengan memasukan konten mengenai metode hidroponik yang akan disedkripsikan Metode yang digunakan dalam kegiatan pelatihan dan pengembangan budidaya sayuran dengan sistem hidroponik pada program GERMAS (Gerakan Masyarakat Sehat) Kelurahan Sindangsari adalah dengan melakukan pelatihan dasar mengenai budidaya tanaman hidroponik.

Materi yang diberikan adalah berupa pengenalan dasar dasar sistem budidaya tanaman dengan sistem hidroponik, yang terdiri dari pengenalan media tanam, benih, nutrisi dan perangkat/alat yang digunahan untuk budidaya sistem hidroponik. Adapun sistem budidaya hidroponik yang digunakan adalah sitem wick sytem yang merupakan sistem yang paling sederhana. Sistem ini merupakan sistem yang paling mudah karena merupakan sistem yang pasif karena tidak ada bagian yang bergerak baik nutrisi maupun mesin. Larutan nutrisi hidroponik diserap oleh tumbuhan melalui media sumbu yang berupa kain flannel maupun bahan lainya yang dapat menyerap air. Alat dan bahan yang digunakan untuk wick system ini adalah tersedia di sekitar rumah, bahkan beberapa alat yang digunakan merupakan peralatan yang sudah tidak terpakai yang merupakan sampah. Berikut ini adalah alat dan bahan yang digunakan :

1. Bak nutrisi hidroponik (Ember bekas, Styrofoam bekas buah, botol bekas air mineral, kaleng bekas cat dll).

2. Media tanam (rockwool, arang sekam, kapas, cocofit dll).

3. Net pot/gelas pelastik.

4. Kain flannel atau bahan lainnya yang dapat menyerap air.

5. Nutrisi hidroponik (AB Mix).

6. Air.

7. Benih.

8. Alat pelubang Styrofoam.

9. Cutter/pisau pemotong.

10. Gunting

Kegiatan pelatihan tingkat dasar yang dilaksanakan diharapkan memberikan pengetahuan dan keterampilan dasar berkaitan dengan budidaya tanaman sistem hidroponik. Beberapa keterampilan yang 


\section{OHernal}

diperoleh para peserta pelatihan pada tingkat dasar ini adalah kemampuan peserta untuk membuat sendiri perangkat yang digunakan dalam budidaya dengan sistem hidroponik dengan memanfaatkan barang bekas seperti botol air mineral, ember bekas maupun Styrofoam bekas buah.

Selanjutnya tahap Nutrient Film Technique (NFT) Sistem merupakan sistem hidroponik yang bekerja dengan cara membagikan air nutrisi pada tanaman melalui aliran air yang tipis. Nutrisi dibuat terus-menerus bersirkulasi menggunakan pompa tanpa menggunakan timer. Pada bagian akar tanaman tidak semua terendam di dalam air nutrisi, sehingga akar yang tidak terendam air tersebut diharapkan mampu mengambil oksigen untuk pertumbuhan tanamannya dalam budidaya dengan sistem hidroponik dengan memanfaatkan barang bekas seperti botol air mineral, ember bekas maupun Styrofoam bekas buah.

Pada tahap akhir Deep Flow Technique (DFT) sistem adalah cara menanam tanaman dengan mensirkulasikan larutan nutrisi tanaman secara terus-menerus selama 24 jam pada rangkaian aliran tertutup. Larutan nutrisi tanaman di dalam tangki dipompa oleh pompa air menuju bak penanaman melalui jaringan irigasi pipa, kemudian larutan nutrisi tanaman di dalam bak penanaman dialirkan kembali menuju tangki.

\section{HASIL DAN PEMBAHASAN}

Kegiatan Tutorial Hidroponik dilakukan secara daring memanfaatkan platform youtube untuk kemudian dibagikan kepada perwakilan ketua RT di kelurahan Sindangsari untuk selanjutnya diteruskan kepada setiap keluarga. Sebagai kegiatan penyampaian inovasi baru, penyampaian informasi tentang budidaya sayuran dengan sistem hidroponik haruslah didukung dengan commitment dari calon adopter. Oleh karena itu diperlukan informasi yang memadai. Berkaitan dengan proses adopsi tersebut terdapat hal yang harus diperhatikan oleh calon adopter: 1) adanya pihak lain yang telah melaksanakan adopsi inovasi dengan berhasil dan sukses; 2) adanya suatu proses adopsi inovasi yang berjalan secara sistematis, sehingga dapat diikuti dengan mudah oleh calon adopter; 3 ) adanya hasil adopsi inovasi yang sukses yang telah memberikan keuntungan, sehingga informasi yang berkaitan dengan inovasi baru akan memberikan dorongan kepada 


\section{Ourrales}

calon adopter untuk melaksanakan adopsi inovasi baru (Soekartawi,2005).

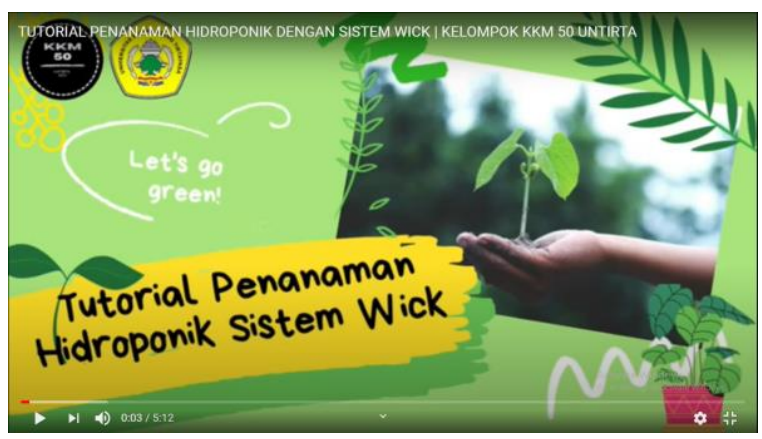

Gambar 1 : Tampilan Awal Tutorial Youtube Hodroponik sistem wick (https://www.youtube.com/watch?v=UzVC $\underline{\mathrm{m}} 4324 \mathrm{mM})$

Berkaitan dengan hal tersebut di atas pelatihan yang dilakukan bukan hanya berkaitan dengan Teknik budidaya sayuran dengan sistem hidroponik saja, akan tetapi dengan menyampaikan beberapa kisah sukses budidaya dengan sistem hidroponik. Tujuannya penyampaian kisah suskses adalah agar peserta pelatihan (calon adopter) termotivasi untuk menerapkannya. Tutorial budidaya sistem hidroponik yang telah dilakukan telah berhasil meningkatkan minat peserta pelatihan, hal tersebut terlihat dengan keseriusan peserta pelatihan dan banyak diantara mereka yang bertanya secara langsung kepada mahasiswa berkaitan dengan materi tutorial yang disampaikan.
Keseriusan peserta pelatihan tersebut dapat di lihat pada pelatihan tingkat dasar maupun pelatihan di tingkat lanjutan.

Apabila dilihat dari capaian yang ingin di peroleh dalam pelatihan tingkat dasar adalah kemampuan peserta dalam mengenal media tanam, benih, nutrisi hidroponik dan peralatan yang digunakan dalam budidaya sayuran dengan sistem hidroponik. Selain itu peserta pelatihan mampu membuat sendiri perangkat sederhana yang digunakan dalam budidaya dengan sistem hidroponik dengan memanfaatkan barang bekas seperti botol air mineral, ember bekas maupun Styrofoam bekas buah. Pelatihan tingkat lanjutan ini dilaksanakan dengan penyampaian teori dan praktek. Beberapa teori yang disampaikan dalam pelatihan adalah :

1. Meramu nutrisi hidroponik

Pada materi tentang pengetahuan dan keterampilan meramu nutrisi hidroponik disampaikan bahwa nutrisi adalah merupakan hal yang penting dilakukan, Sukses berusahatani hidroponik tergantung pada ramuan unsur hara atau nutrisi yang diberikan untuk tanaman. Ramuan nutrisi yang baik akan menghasilkan sayuran yang 
berkualitas baik dan nilai jualnyapun tinggi (Sutiyoso, 2003).

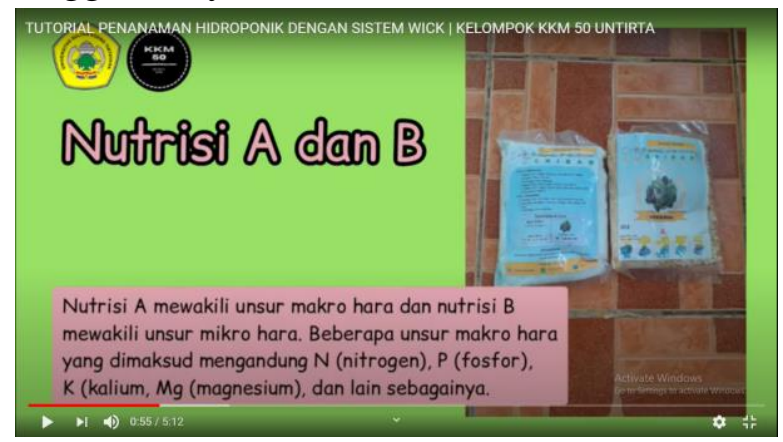

Gambar 2. Tutorial Meramu Nutrisi Hidroponik

(https://www.youtube.com/watch?v=UzVC $\underline{\mathrm{m} 4324 \mathrm{mM})}$

2. Persemaian dan penanaman

Pada materi tentang persemaian dan penanaman ini disampaikan pentingnya cara pemilihan benih yang baik, penyemaian benih yang baik sampai tanaman sayuran tersebut siap tanam. Pemahaman tentang persemaian dan penanaman ini penting karena sangat menentukan optimal tidaknya pertumbuhan tanaman, dengan penyemaian yang baik tumbuhan akan cepat beradaptasi, dan dalam penyemaian tersebut kita juga dapat menyortir tanaman yang baik dan siap untuk ditanam. Inti dari penyampaian materi ini adalah penyemaian dan penanaman adalah merupakan hal yang sangat perlu dilakukan agar tanaman tumbuh dengan optimal dan menghasilkan sayuran yang berkualitas.

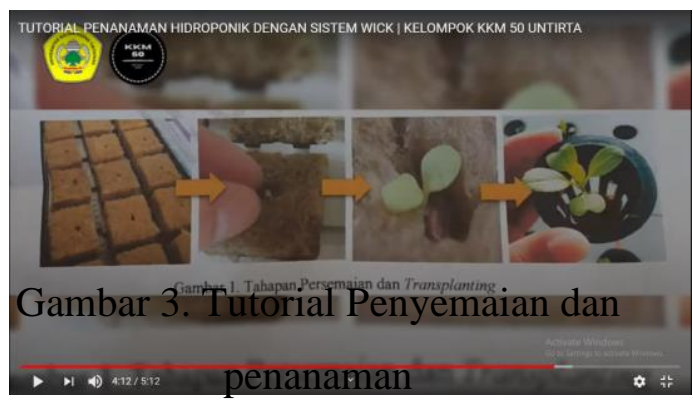

(https://www.youtube.com/watch?v=UzVC $\underline{\mathrm{m} 4324 \mathrm{mM})}$

\section{Pemeliharaan}

Pada penyampaian materi tentang pemeliharaan ini, peserta pelatihan diberikan pemahaman tentang pentingnya pemeliharaan tanaman sayuran dengan sistem hidroponik, materi yang disampaikan adalah : pengecekan kondisi air dalam penampungan dan pipa saluran air, pengecekan kepekatan nutrisi, menjaga kebersihan wadah tanaman, pengecekan kondisi tanaman, pengecekan media tanaman, sortasi tanaman yang tumbuh baik dan tidak baik.

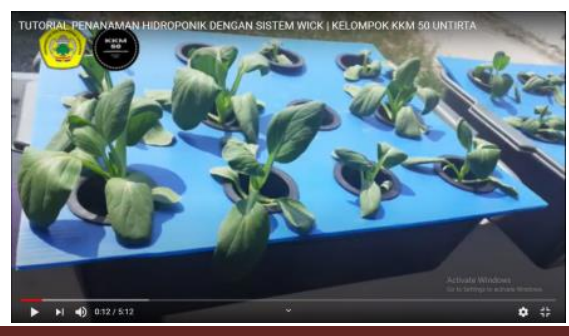


Gambar 4. Pemeliharaan dan Penyemaian (https://www.youtube.com/watch?v=UzVC $\underline{\mathrm{m} 4324 \mathrm{mM})}$

\section{Pengenalan sistem NTF dan DFT}

Pada penyampaian materi tentang pengenalan sistem NTF dan DTF, peserta diberikan pengetahuan berupa keunggulan dan kelemahan serta keterampilan dalam penggunaan kedua sistem hidroponik ini.

Secara umum pelaksanaan pelatihan pada tahapan ini telah berhasil mendorong minat peserta pelatihan, akan tetapi masih terdapat beberapa kekurangan yaitu: 1) peserta pelatihan hanya memahami satu jenis sayuran saja yang di tanam yaitu tanaman pakcoy; 2) sayuran hasil budidaya sistem hidroponik hasil pelatihan belum sesuai dengan harapan, karena masih terlihat kekurangan unsur hara, hal tersebut diakibatkan karena masih lemahnya pemahaman peserta pelatihan tentang unsur hara tanaman (nutrisi hidroponik). Oleh karena itu perlu adanya pelatihan lanjutan tentang penanaman sayuran sistem hidroponik dengan berbagai tanaman sayuran yang berbeda serta pemahaman tentang kepekatan (EC) serta derajat keasaman nutrisi $\mathrm{pH}$ ).
Pemahaman tentang dua hal tersebut di atas sangat penting karena semakin meningkatnya kesadaran masyarakat untuk mengkonsumsi berbagai macam sayuran sebagai sumber gizi keluarga serta peluang pasar masih sangat terbuka. Sehingga membutuhkan pemahaman tentang budidaya hidroponik dengan beberapa sayuran yang berbeda. Selain itu konsumen juga lebih selektif dalam memilih barang yang akan dibelinya. Konsumen mempunyai kecenderungan memilih barang yang berkualitas sehingga seorang produsen harus memahami dan mempunyai keterampilan mengenai cara berproduksi yang baik.

Setelah dilakukan pelatihan, terlihat adanya peningkatan pengetahuan, sikap dan keterampilan peserta pelatihan, hal tersebut dapat dilihat dari adanya peningkatan mutu dan kualitas sayuran yang dihasilkan oleh peserta pelatihan. Sayuran yang dihasilkan lebih segar dan terlihat lebih hijau dibandingkan dengan hasil panen sebelummya. Sehinga dapat disimpulkan bahwa sayuran yang dihasilkan telah memenuhi standar dan siap dipasarkan.

Berdasarkan Tutorial yang telah dilakukan, masyarakat telah mempunyai 


\section{Ourrales}

pengetahuan, sikap dan keterampilan dalam budidaya tanaman sayuran dengan sistem hidroponik. Hal tersebut terlihat dengan tingginya intensitas komunikasi antara masyarakat dan mahasiswa dalam proses penyuluhan informasi mengenai hidroponik. Namun karena tutorial ini bersifat daring dan sementara harus terus dilakukan adalah upaya pembinaan yang terus-menerus secara langsung agar masyarakat mau dan mampu menerapkan ilmu yang diperolehnya.

Apabila pembinaan pengembangan budidaya tanaman sayuran dengan sistem hidroponik dilakukan secara terusmenerus, maka bukan hanya memberdayakan rumah tangga dan masyarakat dalam penyediaan sumber pangan dan gizi melalui optimalisasi pemanfaatan pekarangan dan lahan sekitar tempat tinggal saja, akan tetapi ada hal lain yang bisa diperoleh yaitu kegiatan tersebut dapat meningkatkan kualitas lingkungan dan memperluas kesempatan peningkatan perekonomian karena sayuran yang berasal dari budidaya sistem hidroponik mempunyai nilai jual yang tinggi.

Pengembangan Program Germas melalui budidaya tanaman sayuran sistem hidroponik di Kelurahan Sindangsari Kabupaten Tangerang telah dilaksanakan dan telah memberikan pengetahuan dan keterampilan, akan tetapi ada beberapa hal yang harus diperhatikan yaitu : 1) pelatihan secara langsung dan pembinaannya harus terus dilakukan oleh pihak kelurahan di lingkungan peserta pelatihan dan menumbuhkan sikap dan tanggung jawab dan meningkatkan kesadaran untuk berpartisipasi dalam penyediaan sumber pangan dan gizi keluarga dan tumbuhnya kesadaran tentang pemeliharaan lingkungan; 2) perlu adanya peningkatan pemahaman mengenai potensi pemanfaatan lingkungan yang dalam meningkatkan perekonomian keluarga dengan meningkatkan mutu pelatihan yang menitik beratkan pada pemanfaatan peluang pasar dan aspek pemasaran sayuran hidroponik.

\section{SIMPULAN DAN SARAN}

Berdasarkan uraian tentang pelaksanaan Turorial pelatihan dan pengembangan budidaya tanaman dengan sistem hidroponik yang telah dilaksanakan oleh mahasiswa KKM kelompok 140 Untirta bekerjasama dengan Kelurahan Sindangsari, maka diperoleh beberapa kesimpulan sebagai berikut :

1. Setelah dilakukan tutorial, masyarakat memiliki keterampilan dalam 
membudidayakan sayuran dengan sistem hidroponik dengan berbagai metode yaitu wick system, NFT Sistem (Nutrient Film Technique) dan DFT Sistem (Deep Flow Technique).

2. Setelah dilakukan pelatihan, masyarakat memahami penanganan sayuran setelah panen dan memahami bagaimana strategi yang harus dilakuakan dalam memasaran sayuran sistem hidroponik.

Terdapat beberapa saran berkaitan dengan pelaksanaan pelatihan dan pengembangan budidaya tanaman dengan sitem hidroponik yang telah yaitu:

1. Tutorial dan Pelatihan budidaya sistem hidroponik yang telah dilaksanakan sebaiknya diimplementsikan dalam rangka melaksanakan gaya hidup sehat dengan pola gizi seimbang sesuai dengan Program "GERMAS" (Gerakan Masyarakat Sehat) sebagai upaya pencegahan terhadap gangguan kesehatan keluarga dengan memanfaatlkan lahan pekarangan dengan menggunakan sistem hidroponik.

2. Penerapan hasil pelatihan budidaya sistem hidroponik yang telah dilakukan sebaiknya bukan hanya untuk memenuhi kegutuhan gizi keluarga saja akan tetapi dijadikan sebagai kegiatan yang bermanfaat dalam perekonomian yang bisa meningkatkan taraf hidup.

3. Perlu adanya pelatiahan dan pembinaan yang berkesinambungan dengan meningkatkan mutu pelatihan yang menitik beratkan pada pemanfaatan peluang pasar dan aspek pemasaran sayuran hidroponik

\section{DAFTAR PUSTAKA}

Firmansyah, A. 2018. Perilaku Konsumen (Sikap Pemasaran). Deepublish. Yogyakarta https://id.pinterest.com/pin/5913789947886 75315/ (diakses pada tanggal 3 September 2020)http://www.yoonhidroponik.we b.id/2017/07/hydroponics-deep-flowtechniquesystem.html, (diakses pada tanggal 3 September 2020

Kementerian Pertanian Republik Indonesia. 2018: Petunjuk Teknis Optimalisasi Pemanfaatan Lahan Pekarangan Melalui Kawasan Rumah Pangan Lestari (KRPL).Kementerian Pertanian Indonesia. Jakarta

https://kesmas.kemkes.go.id/assets/upload/d ir_519d41d8cd98f00/files/InpresNomor-1-Tahun-2017-tentangGerakan-Masyarakat-HidupSehat 674.pdf 
Kementrian Hukum dan Hak Asasi Manusia

Republik Indonesia. 2012.

Undangundang Republik Indonesia

nomor 18 tahun 2012, tentang

Pangan. Jakarta.

Kotler, P., Keller, K.L. 2006. Marketing Management. Upper Saddle, New Jersey.

Soekartawi. 2005. Prinsip Dasar Komunikasi Pertanian. UI Press. Jakarta

Sutiyoso, Y. 2003. Meramu Pupuk Hidroponik Tanaman Sayur, Tanaman Buah, Tanaman Bunga. Penebar Swadaya. Jakarta. 